\title{
Sintagmatiese leksikale betrekkinge in Afrikaans
}

\author{
L.G. de Stadler, Departement Afrikaans en Nederlands, Universiteit van \\ Stellenbosch
}

Abstract: Syntagmatic Lexical Relations in Afrikaans. Since the work by Porzig (1934) it has come to be accepted that syntagmatic lexical relations (a type of lexical relation that holds between two lexical items on a syntagmatic level, such as the relationship between dog and bark) has to be incorporated in a theory of lexical structure. Although quite a number of scholars have dealt with the phenomenon over the years, one has to agree that it suffers from a long tradition of neglect. As far as linguistic research in Afrikaans goes, no substantial work has been done. In this article I will contrast syntagmatic relations with its paradigmatic counterparts, draw attention to different types of syntagmatic relations and show what relevance this phenomenon has for lexicography.

Keywords: SYNTAGMATIC LEXICAL RELATIONS, AFRIKAANS, LEXICAL STRUCTURE, PARADIGMATIC LEXICAL RELATIONS, LEXICOGRAPHY

Opsomming: Sedert die werk van Porzig (1934) word daar aanvaar dat sintagmatiese leksikale betrekkinge (' $n$ tipe betekenisbetrekking wat bestaan tussen twee leksikale items op ' $n$ sintagmatiese vlak, soos in die geval van hond en blaf) ook verreken moet word in 'n teorie oor leksikale struktuur. Hoewel verskeie navorsers in die verlede hierdie onderwerp aangespreek het, het dit nie die aandag gekry wat dit verdien nie, veral nie in die Afrikaanse taalwetenskap nie. In hierdie artikel sal ek sintagmatiese leksikale betrekkinge kontrasteer met paradigmatiese leksikale betrekkinge, wys op verskillende tipes sintagmatiese betrekkinge en aantoon watter relevansie hierdie verskynsel vir die leksikografie het.

Sleutelwoorde: SINTAGMATIESE LEKSIKALE BETREKKINGE, AFRIKAANS, LEKSIKALE STRUKTUUR, PARADIGMATIESE LEKSIKALE BETREKKINGE, LEKSIKOGRAFIE

\section{Die leksikon: 'n gestruktureerde geheel}

Die leksikon of woordeskat van 'n taal is 'n gestruktureerde geheel, d.w.s. dit is ' $n$ versameling leksikale items wat (in die reël) in een of ander leksikale betrekking tot mekaar staan. Trouens, dit is dikwels moeilik om 'n leksikale item te verstaan in al sy fyner betekenisonderskeidinge sonder kennis van die leksikale items wat saam met hom deel vorm van dieselfde semantiese veld. Hierdie gestruktureerdheid van die leksikon hou verband met die mens se strukturering of ordening van sy kenniswèreld. Die feit dat diè leksikale item olifant (subor- 
dinaat of hiponiem) in 'n leksikale betrekking staan tot die item dier (superordinaat), $n l$. dié van hiponimie, hou verband met die feit dat 'n olifant as ' $n$ soort dier gesien word. Binne so 'n kognitiewe benadering tot betekenisbeskrywing kan dus gesê word, nié dat die leksikale betekenis van 'n leksikale item 'n funk. sie is van die leksikale betrekkinge wat hy aanknoop nie, maar wel dat die leksikale betrekkinge volg uit die leksikale betekenis van die leksikale item. 'n Mens ken dus wel die betekenis van olifant relatief tot dié van dier. Daarom word die studie van leksikale betrekkinge 'n belangrike heuristiese instrument in die soeke na groter insig in die aard van leksikale betekenis en leksikale struktuur.

Verskillende tipes leksikale betrekkinge kan onderskei word. Die volgende tipes het in taalbeskrywing tot dusver heelwat aandag geniet:

a. sinonimie, 'n leksikale betrekking wat bestaan tussen twee items waarvan die betekenisse in 'n hoë mate ooreenstem, bv. vader vs. pa;

b. teenoorgesteldheid, ' $n$ leksikale betrekking wat bestaan tussen twee items waarvan die betekenisse in opposisie tot mekaar staan, bv. hoog vs. laag;

c. hiponimie, 'n leksikale betrekking wat bestaan tussen twee leksikale items waarvan die een se betekenis die betekenis van die ander "insluit", bv. meubel vs. stoel, of die reedsgenoemde voorbeeld dier vs. olifant.

Hierdie leksikale betrekkinge het een kenmerk gemeen: hulle is almal voorbeelde van paradigmatiese betrekkinge. In die leksikon bestaan daar egter ook sintagmatiese leksikale betrekkinge, d.w.s. daardie betrekkinge wat volg uit die feit dat twee of meer leksikale items heel voorspelbaar met mekaar verbind op sintagmatiese vlak (De Stadler 1989: 91),, soos in die volgende voorbeelde:

voet $\times$ skop, tong $\times$ lek, dier $\times$ poot, water $\times$ vloei, wyn $\times$ vat, vlieg tuig $\times$ lug, skryf $\times$ pen, sny $\times$ mes, ens.

Of te wel: Wat is dit waarmee ' $n$ mens skop? ' $n$ Voet. Wat is dit wat ' $n$ poot het? 'n Dier. Waarmee skryf 'n mens? 'n Pen. Hierdie vraag-en-antwoord-pare weerspieël op die mees direkte wyse die aard van sintagmatiese betekenisbetrekkinge.

Anders as in die geval van die paradigmatiese leksikale betrekkinge, word daar in die leksikale semantiek bitter min aandag aan dié betrekking bestee, en

Ek erken met waardering die werk wat deur 'n aantal voor- en nagraadse studente oor hierdie onderwerp gedoen is, veral hulle moeite met die versameling van data en hulle soms uitstekende voorstelle or bepaalde probleme. Ek sonder hier graag die name van Helena van Schalkwyk en Annelize Krüger uit. 
In die Afrikaanse semantiek feitlik geen aandag nie.2 Die gebrekkige aandag laat na my mening nie reg geskied aan die belangrikheid van hierdie betrekking nie. Dit is dikwels so dat die voorbeelde wat aangehaal word om die verskynsel te illustreer, so banaal eenvoudig is dat die belangrikheid daarvan onderskat word.

Dit is die doel van hierdie artikel om die begrip sintagmatiese leksikale betrekking aan die orde te stel en te wys op enkele probleme rondom dié begrip.

\section{2. \\ Die aanloop}

Die konsep van 'n sintagmatiese leksikale betrekking kan herlei word tot die werk van Porzig (1934). In teenstelling met die werk van Trier en Weisgerber, wat die klem geplaas het op die paradigmatiese semantiese verhoudings wat daar tussen leksikale items mag bestaan in 'n semantiese veld, het hy die klem laat val op die sintagmatiese betrekkinge wat leksikale items met mekaar aangaan. Hoewel daar aanvanklik gedebatteer is oor die aanvaarbaarheid van twee oënskynlik opponerende standpunte, word daar vandag aanvaar (saam met die opponente Trier en Porzig) dat daar in enige aanvaarbare teorie oor leksikale struktuur rekenskap gegee moet word van paradigmatiese en sintagmatiese leksikale betrekkinge. Porzig het die aandag gevestig op die essensiële betekenisbetrekking ("wesenhafte Bedeutungsbeziehung") tussen sintagmas soos byt $\times$ tande, blaf $x$ hond, lek $\times$ tong, ens. (Lyons 1977: 261).

\section{Die begrensing van die verskynsel}

\subsection{Tipes sintagmatiese betekenisbetrekkinge}

'n Mens sal op prinsipiële gronde moet onderskei tussen verskillende tipes sintagmatiese betrekkinge wat vir die semantiek in die algemeen en vir die leksikale semantiek in die besonder van belang is. Hieronder tel die volgende opvallende subtipes:

a. daardie betrekkinge wat tradisioneel bekend staan as sg. seleksiebeperkings, d.w.s. betrekkinge wat geld tussen semantiese kenmerke van leksikale items en nie soseer tussen die items self nie (die Katz-en-Fodor-benadering);

2 Vergelyk Lyons (1977: 261-266) vir enkele inleidende gedagtes. Van hierdie gedeelte word dankbaar gebruik gemaak. Die klassieke werk waarna altyd verwys word wanneer oor hierdie tipe betekenisbetrekking gepraat word, is dié van Porzig (1934). 
b. kollokasies, d.w.s. sintagmatiese betrekkinge tussen leksikale items wat nie sigbaar volg uit die betekenisse van die onderskeie items nie, soos in a. en c.; en

c. sintagmatiese leksikale betrekkinge, d.w.s. daardie betrekkinge wat geld tussen twee of meer leksikale items op sintagmatiese vlak (die Porzig-benadering).

Seleksiebeperkings geniet veral in die generatiewe paradigma reeds jare lank besondere aandag, veral na aanleiding van die werk van Katz en Fodor, en kan beskou word as een van die uitvloeisels van die werk van Porzig. Hierdie tipe sintagmatiese betekenisbetrekking kan verduidelik word met die hulp van ' $n$ voorbeeld soos die werkwoord slaan, 'n woord waarvan die sintagmatiese gedrag beperk is, want hy moet verbind met ' $n$ onderwerp wat die kenmerk [+ lewend] moet hê, terwyl die direkte voorwerp die kenmerk [+ fisiese objek] moet hè. Hierdie gegewens kan dan as seleksiebeperkings in die definisie van die betrokke leksikale item opgeneem word. Binne die generatiewe paradigma word hierdie verhoudings op heel diskrete wyse beskryf binne die leksikon, wat op sy beurt weer deel vorm van die basiskomponent wat 'n onderdeel is van die (wesenlik) sintaktiese komponent van die grammatika. Soos De Stadler (1989: 104-105) aantoon, lei hierdie benadering tot die beskrywing van sintagmatiese leksikale betrekkinge egter tot 'n onsimpatieke, ongenuanseerde beskouing van leksikale betekenis, want dit gee geen rekenskap van die ensiklopediese status van seleksiebeperkinge, die prototipiese aard van leksikale betekenis en die (gevolglike) semantiese vryheid van leksikale items nie. 'n Sin soos

Die kos maak 'n draai.

mag lyk asof dit ' $n$ anomalie bevat omdat die predikaat ' $n$ draai maak ' $n$ onderwerp eis met die kenmerk [+ beweging], maar dit hou nie rekening met die taalgebruik van ' $n$ uithalerkok wat skeppend met sy of haar taal omgaan en met bg. sin te kenne gee dat die kos 'n besondere geur het nie. Uiteindelik kan seleksiebeperkings maar net gesien word as meganismes waarin verwagtings verwoord word wat betrekking het op die buitetalige werklikheid wat deur die taalgegewe beskryf word. Daarom het seleksiebeperkings eerder ensiklopediese status, want die verwagtings wat hulle beskryf "zijn veronderstellingen over de werkelijkheid, en als zodanig maken ze deel uit van een wereldbeeld veeleer dan van een outonome talstructuur" (Geeraerts 1986: 131). Hierdie standpunt is natuurlik aanvaarbaar binne ' $n$ kognitiewe benadering tot leksikale betekenis, want binne die kognitiewe paradigma is die verskil tussen taalkundige en ensiklopediese kennis 'n graduele verskil.

As seleksiebeperkings gesien kan word as een punt van 'n skaal van stereotiepe sintagmatiese betekenisbetrekkinge waar leksikale items se optrede gekondisioneer word deur semantiese onderskeidende kenmerke, kan mens 
verwag dat daar op die teenoorgestelde punt van die skaal leksikale items moet wees wat met mekaar een of ander sintagmatiese verhouding aangaan wat volkome vas of geyk is, d.w.s. dit is hoegenaamd nie duidelik dat die beperkings op hulle sintagmatiese optrede berus op die betekenisse van die konstituerende dele van die betrokke sintagma nie. Vergelyk in dié verband die semantiese veld van leksikale items wat verwys na versamelings/groepe diere en die sintagmatiese verbande waarin hulle optree (De Stadler 1989: 105-106):

$$
\begin{aligned}
& \text { 'n trop skape } \\
& \text { 'n kudde diere } \\
& \text { 'n swerm voëls } \\
& \text { "n kudde skape } \\
& \text { "n swerm diere } \\
& \text { "n trop voëls }
\end{aligned}
$$

In al die versamelname in die voorbeelde is die gemeenskaplike betekenismoment "versameling". Dit is egter nie duidelik hoe die betekenisse van die leksikale items in die onderskeie sintagmas die sintagmatiese verbande moet verklaar nie: hoekom sal trop nou juis met skape verbind en swerm met voëls, en nie omgekeerd nie? Hierdie (byna volledig) geykte sintagmatiese leksikale betrekkinge word kollokasies genoem.

In hierdie bydrae sal daar gefokus word op sintagmatiese leksikale betrekkinge, d.w.s. 'n betrekking wat bestaan tussen twee of meer leksikale items op grond van hulle betekenisse, en wat gesien kan word as 'n betrekking wat 'n posisie op die skaal beklee wat lê iewers tussen seleksiebeperkings (nie geyk nie) en kollokasies (hoogs geyk).

\subsection{Sintagmatiese leksikale betrekkinge}

In die eerste plek gaan dit in 'n sintagmatiese leksikale betrekking om 'n redelik stereotiepe (geykte) verbinding. Dit is byvoorbeeld so dat die woord blaf op sintagmatiese vlak allereers die item hond oproep. Die sintagmatiese verbinding Honde blaf het m.a.w. met verloop van tyd vergroei tot ' $n$ geykte/assosiatiewe verhouding sodat die betekenis van blaf vandag nie meer beskryf kan word sonder inagneming van hierdie (geykte) sintagmatiese verhouding nie. Die twee leksikale items het dus 'n (vaste) sintagmatiese leksikale betrekking met mekaar aangegaan. Blaf kan egter ook met koedoe verbind, want van koedoes kan ook gesê word dat hulle blaf. Dit sou egter neerkom op 'n verarming van die begrip sintagmatiese leksikale betrekking om die paar koedoe en blaf daaronder in te sluit, want dit ontken die prototipiese verhouding wat bestaan tussen hond en blaf. 
Die voorbeelde wat tot nou toe van hierdie verskynsel aangebied is, was redelik eenvoudige voorbeelde. Die vraag is egter na die mate waarin hierdie verskynsel van toepassing is op alle leksikale items. Soos Lyons (1977: 261-262) aandui, is daar talle leksikale items wat vanweë hulle algemene betekenis 'n hoë graad van verbindbaarheid vertoon, soos bv. goed, groot, mooi, ens. Hierdie leksikale items kan met 'n groot verskeidenheid ander items verbind en verbind met geen enkele leksikale item in 'n stereotiepe verbinding nie, d.w.s. hulle tree nie werklik in 'n sintagmatiese leksikale betrekking met ander leksikale items op nie. Daarteenoor verbind ' $n$ item soos blaf feitlik net met hond, soos ook in die geval van galsterig $\times$ botter, tong $\mathrm{x}$ lek, perd $\mathrm{x}$ runnik, ens.

Van die stereotiepe gevalle kan 'n mens sê dat hulle 'n essensiële betekenisverhouding weerspieel: dit is byna ondenkbaar dat jy byvoorbeeld die betekenis van lek sal beskryf sonder om te verwys na die sintagmatiese verband wat tussen dié item en die leksikale item tong bestaan. Die verhouding kom neer op die enkapsulering (opname) van die een leksikale item se betekenis in dié van die ander. In die geval van tong en lek beteken dit dat tong se betekenis in dié van lek geënkapsuleer (opgeneem) word.

Die belangrikste vraag (ook van Lyons) is egter na die teoretiese relevansie van hierdie betrekking. Dit kan ten beste gemotiveer word met ' $n$ paar leksikale items wat in paradigmatiese kontras teenoor mekaar staan, nl. voet en poot. Albei hierdie items bevat 'n gemeenskaplike betekeniskomponent wat ek hier sal aandui as (L. pes) na die Latyn. In die een geval verbind hierdie betekeniskomponent sintagmaties met van ' $n$ mens en in die ander met van ' $n$ dier:

$$
\begin{aligned}
& \text { voet }=(\text { L. pes })+\text { van 'n mens } \\
& \text { poot }=(\text { L. pes })+\text { van 'n dier }
\end{aligned}
$$

In hierdie gevalle het die sintagmatiese betrekking dus in die woord geleksikaliseer geraak deur die enkapsulering van die een deel van die sintagma in die ander. Hierdie woorde se betekenisse kan nie van mekaar onderskei word sonder verwysing na die verskil in die sintagmatiese leksikale betrekkinge wat hulle aangaan nie. Vergelyk ook voorbeelde soos skop vs. slaan (Lyons se voorbeeld) waarin die betekenisse "met 'n voet" en "met 'n vuis" onderskeidelik geleksikaliseer geraak het, of die voorbeeldpaar seil vs. vaar wat onderskeidelik die leksikalisering is van "beweeg met 'n seiljag" en "beweeg met 'n skip".

Wanneer ' $n$ leksikale item voortdurend in 'n sintagma optree saam met 'n ander leksikale item, vind daar met verloop van tyd 'n stereotipering van die verhouding plaas en ontstaan daar ' $n$ sintagmatiese leksikale betrekking wat inhou dat die een leksikale item se betekenis in dié van die ander geënkapsuleer word. Soms is die graad van stereotipering so hoog dat stereotipering van die verhouding eintlik oorgaan in yking van die verhouding, soos in die geval van blond en hare. Die hoogste graad van yking word dan, soos reeds vroeër gese, kollokasie genoem. Nie alle sintagmatiese leksikale betrekkinge 
vertoon dieselfde graad van yking nie, ' $n$ toedrag van sake wat in verband gebring moet word met die prototipiese aard van leksikale betekenis. Hieroor meer in paragraaf 6.

Die beskrywing van sintagmatiese leksikale betrekkinge het ook binne die kognitiewe paradigma van taalbeskrywing ' $n$ besondere relevansie. Om dit te begryp moet ' $n$ mens kennis neem van die grondliggende aannames van die kognitiewe semantiek:

a.

Betekenis is gegrond op konseptualisering, 'n kognitiewe proses waarin allerlei veranderlikes betrek word, waaronder die hantering van nuwe of eienaardige konsepte, sensoriese ervaring en kennis van die konteks waarin ' $n$ talige item funksioneer.

b. $\quad$ 'n Leksikale item is normaalweg polisemies, d.w.s. dit het 'n verskeidenheid verwante betekenisse wat 'n kategorie van betekenisse vorm wat as ' $n$ betekenisnetwerk voorgestel kan word.

c.

Die betekenis van ' $n$ leksikale item of ' $n$ meer komplekse uitdrukking moet gekarakteriseer word met betrekking tot een of meer kognitiewe domeine. Enige vorm van gedrag, ondervinding, 'n verwante konsep, 'n konseptuele kompleks of 'n kennissisteem kan dien as so 'n kognitiewe domein teen die agtergrond waarvan die betekenis van 'n talige item beskryf moet word.

d. Die betekenis van ' $n$ leksikale item hou een of ander vorm van konvensionele beelding ("conventional imagery") in, d.w.s. hierdie betekenis inkorporeer ' $n$ besondere wyse van konstruering van die konseptuele inhoud van ' $n$ leksikale of meer komplekse item soos wat bepaal word deur die kognitiewe domein van daardie item. ${ }^{3}$

Binne die kognitiewe semantiek gaan dit dus ook om konsepte wat interafhanklik is, en dit is dan juis op hierdie punt dat sintagmatiese leksikale betrekkinge ter sake is, want binne so 'n betrekking roep die een leksikale item die konseptuele raamwerk op wat die domein vorm waarbinne die betekenis van die ander leksikale item verstaan moet word. In 'n voorbeeld soos hond $\mathrm{x}$ blaf word die enkapsulering van die betekenis van hond in dié van blaf soos volg gesien: hond roep die kognitiewe domein op waarbinne die betekenis van blaf gekarakteriseer moet word, d.w.s. hond word een van die konseptuele komponente van blaf. Die konteks waarin 'n bepaalde item hom (voortdurend) be-

Hierdie uiters kriptiese beskrywing van die basisaannames van die kognitiewe semantiek het ek te danke aan 'n lesingreeks deur Ronald Langacker tydens 'n kongres (Language, Thought and Culture) wat in April 1991 by Broederstroom gehou is. Beperkte ruimte verbied my om meer as hierdie kriptiese aanbod te gee. Die belangrikste begrippe in die kognitiewe semantiek word hanteer in Langacker (1987, 1991), Lakoff (1987), Lakoff en Johnson (1980), Rudzka-Ostyn (1985; vgl. veral die inleidende artikels van Langacker in hierdie bundel), en Fauconnier (1984). 
vind, speel dus uiteindelik ' $n$ rol. Langacker (1987: 156) verduidelik dit self soos volg: "From the encyclopedic nature of contextual meaning, that of conventional meaning follows fairly directly. The latter is simply contextual meaning that is schematized to some degree and established as conventional through repeated occurrence." (My kursivering - L.G. de S.) Hiermee word die wesenlike belang van sintagmatiese leksikale betrekkinge vir die kognitiewe semantiek dan netjies in reliëf geplaas: behoorlike kennisname van die sintagmatiese leksikale betrekkinge wat leksikale items met mekaar aangaan, lei tot 'n groter begrip van die konseptuele domeine ten opsigte waarvan hierdie items se betekenisse gekarakteriseer moet word.

Hierdie kognitiewe benadering tot betekenis impliseer "dat die onderskeid tussen semantiese en ensiklopediese kennis vervaag: daar word veel eerder uitgegaan van 'n skaal van ensiklopedisiteit waarop sekere kennis opvallender/belangriker/voorspelbaarder is as-ander. Dit het die belangrike implikasie dat kennis van die wêreld veel direkter in die taalsisteem gereflekteer word: leksikale kategorieë of velde word dan kategorieë wat in die eerste plek ons kennis van die wêreld struktureer" (De Stadler 1989: 59). As ons konseptualisering van galsterig dan insluit dat dit eintlik maar van botter geld, moet ons betekenisbeskrywing van die betrokke leksikale item dit weerspieël en verval die kritiek wat tradisioneel ingebring sou kon word teen die volgende definisie wat die Verklarende Handwoordeboek van die Afrikaanse Taal gee, nl. dat dit ensiklopediese inligting sou bevat:

(4) galsterig: "... Met 'n slegte, walglike smaak soos dié van botter wat lank oopgestaan het en al sleg is ..."

en sou 'n mens juis die definisie van Nasionale Woordeboek kon kritiseer omdat hierdie inligting ontbreek:

$$
\text { galsterig: "... Ou vet smaak ..." }
$$

\section{Enkapsulering: bilateraal of unilateraal?}

Die vraag kan nou gestel word na die rigting waarin die enkapsulering plaasvind. Twee moontlikhede doen hulle voor:

a. enkapsulering vind unilateraal (eensydig) plaas, d.w.s. die betekenis van die een leksikale item in die sintagmatiese leksikale betrekking word in dié van die ander geënkapsuleer, maar nie omgekeerd nie; of

b. enkapsulering vind bilateraal plaas, d.w.s. die betekenis van die een leksikale item word in dié van die ander geënkapsuleer en omgekeerd. 
In voorbeelde soos blond $\mathrm{x}$ hare en vis $\mathrm{x}$ water vind die enkapsulering unilateraal plaas. Die betekenis van die leksikale item blond kan beswaarlik beskryf word sonder verwysing na die konseptuele domein wat die betekenis van die selfstandige naamwoord hare oproep. Dit is egter nie so dat die betekenis van hare in betekenisimplikasie m.b.t. blond insluit nie. Op dieselfde manier word die betekenis van water in die betekenis van vis geënkapsuleer, maar nie omgekeerd nie.

Die sintagmatiese leksikale betrekking tussen hoor en oor is egter 'n bilaterale betekenisbetrekking: in albei gevalle kan die betekenis van die een leksikale item beswaarlik beskryf word sonder verwysing na die konseptuele domein wat die ander oproep. Die enkapsulering vind dus wedersyds plaas, soos blyk uit die leksikale definisies wat die Verklarende Handwoordeboek van die Afrikaanse Taal van dié twee leksikale items gee (definisies slegs gedeeltelik aangehaal):

(6) hoor: "Met die oor waarneem ..."

oor: "Sintuig van die gehoor ..."

Oor die presiese aard van die enkapsulering word iets meer gesê nadat die vernaamste tipes van mekaar onderskei is, maar daar kan reeds in hierdie stadium gewys word op die feit dat die oorgrote meerderheid sintagmatiese leksikale betrekkinge unilaterale betrekkinge is.

\section{Verskillende tipes sintagmatiese leksikale betrekkinge}

\subsection{Die verband met rolgrammatika}

Omdat ' $n$ mens hier te make het met semantiese verhoudings op ' $n$ sintagmatiese vlak, kan jy verwag dat dieselfde semantiese verhoudings wat op sintakties-semantiese vlak aangetref word, in hierdie tipe leksikale betrekking neerslag sal vind. Die semantiese struktuur van 'n sin soos

Randall breek sy ma se hart met sy ontrouheid.

kan nie net beskryf word in terme van sintaktiese begrippe soos onderwerp, direkte voorwerp, ens. nie, maar moet ook beskryf word in terme van rolgrammatikale begrippe soos doener, pasiënt, instrument, ens., want in 'n sin soos

$$
\text { Sy ontrouheid breek sy ma se hart. }
$$

het die sintaktiese verhoudings wel verander (in hierdie geval het die aanvulling van die setsel met die onderwerpsposisie ingeneem), maar die semantiese 
verhouding tussen werkwoord en argument het konstant gebly (in albei sinne funksioneer die naamwoordstuk sy ontrouheid as instrument van die handeling).

Daar is ' $n$ verskeidenheid rolgrammatikale begrippe wat ter sake is en die ruimte ontbreek om elkeen van hulle in besonderlrede te beskryf. In die meeste gevalle is die aard van die betrokke rol deursigtig en daarom word hier volstaan met 'n kriptiese karakterisering van enkeles:

doener: die rol van die deelnemer wat die handeling uitvoer of veroorsaak (in De Stadler (1989) word onderskei tussen doeners en agente);

pasiënt: die rol van die deelnemer wat die handeling ondergaan;

instrument: die (prototipies lewelose fisiese) objek met die hulp waarvan die handeling uitgevoer word;

lokatief: die plek waar die handeling uitgevoer word.

Sintagmatiese leksikale betrekkinge vertoon 'n tipologiese verskeidenheid wat in hierdie rolgrammatikale terme beskryf kan word, 4 terme wat verwys na begrippe wat, vanweë hulle inherent prelinguistiese aard (hulle verwys immers na konstrukte wat allereers in die ervaringswêreld van sprekers voorkom), op besondere wyse aantoon hoe betekenis (ook leksikale betekenis) die mens se konseptualisering van sy ervaringswêreld weerspieël.

\subsection{Doener-handeling-verhouding}

In die volgende gevalle kan die sintagmatiese verhouding tussen die lede van elke paar beskryf word as die verhouding tussen doener en handeling:

(9) water $x$ kabbel, vis $x$ duikel, perd $\times$ galop, hond $\times$ blaf, bees $x$ bulk, hen $x$ kekkel, voël $x$ vlieg, donkie $x$ balk, muil $x$ balk, esel $x$ balk, skaap $\times$ blêr, bok $\times$ blêr, vuur $\times$ brand, bal $\times$ hop, dokter $x$ genees, koning $x$ regeer, dief $x$ steel, ballerina $x$ dans, wind $x$ dwarrel, koor $x$ sing, ens.

In die meerderheid gevalle word die betekenis van die doenernaamwoord in die betekenis van die werkwoord geënkapsuleer. Een van die opvallende subtipes in hierdie geval is dié een waar die werkwoord na 'n geluid verwys. Daar is egter ook gevalle waar die betekenis van die werkwoord in die betekenis van die doenernaamwọord geënkapsuleer word, soos bv. koning $\times$ regeer, dief $x$ steel, dokter $\times$ genees, ens. In hierdie gevalle is die leksikale betrekking dus bilateraal. 
53 Doener-pasiënt-verhouding

Naas bg. kategorie is daar ook 'n kategorie van sintagmatiese leksikale betrekkinge waarin daar' $n$ yking van die verhouding tussen doener en pasiënt voorkom:

(10) kuiper $x$ vate, beiaardier $\times$ klokke, veearts $x$ diere, apteker $x$ medisyne, pianis $x$ klavier, barbier $x$ hare, pediater $x$ kinders, ens.

In hierdie gevalle is die leksikale betrekking ' $n$ unilaterale betrekking met die betekenis van die pasiëntnaamwoord wat in die betekenis van die doenernaamwoord geënkapsuleer word.

\subsection{Lokatiewe verhouding}

In die volgende gevalle is daar ' $n$ lokatiewe verhouding wat in die leksikale betrekking vasgelê word:

(11) a. skip $\times$ kaai, geld $\times$ bank, motor $\times$ garage, wyn $\times$ vat, voël $x$ kou

b. liasseer $\times$ lêers, swem $\times$ water, sit $x$ stoel, slaap $x$ bed

Verskillende tipes kan onderskei word: Die eerste hooftipe is dié tussen twee naamwoorde waarvan die een verwys na 'n saak en die ander na die lokaliteit waarmee die saak geassosieer word, soos in (11a). Onder hierdie hooftipe kan verskillende semantiese subtipes onderskei word:5

a. Die "werkplek"-kategorie, bv. koster $\mathrm{x}$ kerk, hanswors $\mathrm{x}$ sirkus, prinsipaal $\mathrm{x}$ skool, rektor $\times$ universiteit, blokman $\times$ slaghuis, kurator $\times$ museum, ens. In die meerderheid gevalle in hierdie kategorie word die betekenis van die naamwoord wat na die "werkplek" verwys, in die betekenis van die "werker"-naamwoord geënkapsuleer.

b. Die "blyplek"-kategorie, bv. voël $\times$ nes, by $\times$ korf, perd $\times$ stal, voël $\times$ kou, spinnekop $\times$ web, non $\times$ klooster, ens. Anders as in die gevalle by a. werk die enkapsulering hier andersom: die naamwoord wat na die "blyer" verwys se betekenis word in die lokatiewe naamwoord se

5 Die idee vir hierdie indeling het ek te danke aan mej. Annelize Krüger, wat 'n werkstuk oor die betrokke onderwerp gedoen het. 
betekenis geënkapsuleer. Daar is uitsonderings wat hierdie enkapsuleringsrigting betref, soos engel $\times$ hemel, vis $\times$ water, mol $\times$ grond, ens. In hierdie gevalle verwys die lokaliteitsname na heel algemene lokaliteite in die buitetalige werklikheid.

c. Die "gebruikplek"-kategorie, bv. hoed $\times$ kop, serp $\times$ nek, kasregister $\times$ winkel, pipet $x$ laboratorium, spyskaart $\times$ restaurant, ens. In dié gevalle word die betekenis van die lokaliteitsnaamwoord in die betekenis van die gebruiksartikelnaamwoord geënkapsuleer.

d. Die "bergplek"-kategorie, bv. wyn $\times$ vat, kers $\times$ blaker, water $\times$ dam, drank $\times$ kroeg, wapens $\times$ arsenaal, motor $\times$ garage, ens. In die oorgrote meerderheid van hierdie gevalle word betekenis van die gebruiksartikelnaamwoord in dié van die lokaliteitsnaamwoord geënkapsuleer.

e. Die "aantrefplek"-kategorie, bv. skulpe $\times$ strand, slyk $\times$ water, bles $\times$ kop, room $\times$ melk, ens. In hierdie gevalle is dit die lokaliteitsnaamwoord se betekenis wat in dié van die ander naamwoord opgeneem word. Dit wil my voorkom asof subkategorieë c. en e. een kategorie vorm.

Die ander hooftipe sluit daardie gevalle in waar daar 'n leksikale betrekking bestaan tussen die werkwoord en die lokaliteitsnaamwoord, soos in (11b). In dié gevalle is dit die betekenis van die lokaliteitswoord wat in die betekenis van die werkwoord geënkapsuleer word.

\subsection{Instrumentverhouding}

Die assosiasie tussen 'n werkwoord en die naamwoord wat die instrument beskryf met die hulp waarvan 'n handeling uitgevoer word, kan ook so sterk word dat ' $n$ sintagmatiese leksikale betrekking ontstaan:

(12) slaan $\times$ sambok, veg $\times$ sabel, gaap $\times$ mond, gaffel $\times$ vurk, ry $\times$ motor, koop $\times$ geld, kyk $\times$ oog, skryf $\times$ pen, vlieg $\times$ vlerke, spit $\times$ graaf, vee $x$ besem, verf $x$ kwas, knip $\times$ skêr, skryf $\times$ pen, byt $\times$ tande, skop $\times$ voet, krap $\times$ naels, lek $\times$ tong, pleister $\times$ troffel, ens.

In hierdie kategorie is daar ' $n$ beduidende aantal gevalle (meer as $50 \%$ van die ondersoekte data) waarin die verhouding tussen die twee leksikale items bilateraal is, d.w.s. enkapsulering vind plaas in albei rigtings, soos in die geval van skryf $x$ pen, waar die betekenis van skryf in dié van pen geënkapsuleer is en omgekeerd. Dit is ook die geval in koop $\times$ geld, kyk $\times$ oog, spit $\times$ graaf, vee $\times$ besem, verf $x$ kwas, ens. Daar is egter ook gevalle waarin die verhouding unilateraal is, soos in skop $\times$ voet, gaap $\times$ mond, byt $\times$ tande, lek $\times$ tong, ens. (instrumentbetekenis geënkapsuleer in die betekenis van die werkwoord) of pleister $\times$ troffel, slaan $\times$ 
sambok, ens. (werkwoordbetekenis geënkapsuleer in die betekenis van die naamwoord wat na die instrument verwys).

Instrumentnaamwoorde gaan egter ook sintagmatiese leksikale betrekkinge aan met 'n pasiëntnaamwoord, soos in

(13) harpoen $x$ walvis, vingerhoed $x$ naaldwerk, stemvurk $x$ musiekinstrumente, sjampoe $x$ hare, ens.

In al die gevalle in dié kategorie is die verhouding unilateraal: die betekenis van die pasiëntnaamwoord word in die betekenis van die instrumentnaamwoord geënkapsuleer.

\subsection{Pasiëntverhouding}

Die pare in (14) is voorbeelde waarin daar ' $n$ sintagmatiese leksikale betrekking bestaan tussen 'n werkwoord en 'n pasiëntnaamwoord:

(14) saag $\times$ hout, adresseer $\times$ brief, lees $\times$ boek, knoop $\times$ tou, pos $\times$ brief, stop $\times$ gat, eet $\times$ kos, aanbid $\times$ gode, parkeer $\times$ voertuig, roskam $\times$ perd, ploeg $\times$ grond, saai $x$ saad, kalfater $x$ skip, parkeer $x$ voertuig, skop $\times$ bal, sing $\times$ lied, brei $\times$ trui, lui $\times$ klok, ontsyfer $\times$ handskrif, blus $\times$ vuur, sloop $\times$ gebou, snuit $\times$ neus, beredder $\times$ boedel, stryk x klere, ens.

Die verhouding tussen die leksikale items in hierdie kategorie is normaalweg unilateraal: die betekenis van die pasiëntnaamwoord word geënkapsuleer in die betekenis van die werkwoord. Daar is enkele gevalle wat onseker is, soos bv. sing $x$ lied, wat as 'n bilaterale leksikale betrekking gesien sou kon word, d.w.s. waar die betekenis van die werkwoord in dié van die pasiëntnaamwoord geënkapsuleer word.

\subsection{Kenmerkverhouding}

In die volgende voorbeeldpare is die sintagmatiese leksikale betrekking tussen ' $n$ naamwoord en ' $n$ adjektief en word die attribuut wat deur die adjektief benoem word normaalweg in die betekenis van die naamwoord geënkapsuleer. Daar is egter uitsonderings, soos in die verhouding tussen blond en hare:

(15) gal $\times$ bitter, aalwyn $\times$ bitter, sneeu $x$ wit, blaar $\times$ groen, ys $\times$ koud, ring $x$ rond, naald $x$ skerp, suiker $x$ soet, blond $x$ hare, ens. 
die prototipiese waarde wat deur die sintagmatiese verhouding gesuggereer word, vind dikwels neerslag in ' $n$ samestelling tussen die twee lede van die sintagma, soos in galbitter, sneeuwit, blaargroen, yskoud, naaldskerp, suikersoet, ens.

\subsection{Possessiefverhouding}

Die volgende voorbeelde is ter sake:

(16) kroon $\times$ koning, borslap $\times$ baba, spykerskoene $x$ atleet, rolstoel $x$ verlamde, gidshond $x$ blinde, stetoskoop $\times$ geneesheer, ens.

Die term possessief moet hier baie wyd geïnterpreteer word. 'n Mens kan hoogstens sê dat al hierdie gevalle geparafraseer kan word in 'n possessiefkonstruksie:

(17) die koning se kroon, die baba se borslap, die atleet se spykerskoene, die verlamde se rolstoel, ens.

In hierdie gevalle is dit die "besitting" wat die betekenis van die "besitter"naamwoord in hom opneem.

\subsection{Die relevansie van ' $n$ tipologiese benadering}

Met hierdie kort oorsig oor verskillende tipes is die terrein beslis nog nie uitgeput nie. 'n Mens sou 'n temporele verhouding kon onderskei in gevalle soos

(18) slaap $\times$ nag, ontbyt $\times$ oggend

en 'n verhouding van oorsprong of herkoms in gevalle soos

(19) melk $x$ koei, goud $x$ myn, brood $x$ koring, wyn $x$ druiwe, botter $x$ room, ens.

Uiteindelik is ' $n$ tipologiese benadering tot die verskynsel van groot belang, veral binne ' $n$ kognitiewe raamwerk, want die verskillende tipes weerspieël bepaalde konseptuele strukture in die leksikon wat op hulle beurt weer 'n weerspieëling is van die wyse waarop die mens sy kenniswêreld struktureer. 
6.

\section{Stereotipering van die verhouding}

Teen die agtergrond van die kognitiewe siening van woordbetekenis waarmee in hierdie studie gewerk word, moet mens nou verwag dat die sintagmatiese leksikale betrekking wat daar tussen twee leksikale items bestaan, verskillende grade van skematisering kan vertoon. Skematisiteit kan vergelyk word met die verhouding tussen 'n superordinaat en 'n subordinaat, of in die geval van sintagmatiese leksikale betrekkinge, die verhouding tussen die enkapsulerende item en die geënkapsuleerde item. Die geënkapsuleerde item verteenwoordig dan 'n uitbreiding of detaillering van die skema. Skematisiteit gee ook aanleiding tot geyktheid, want hoe sterker die skematisiteitsverhouding tussen twee items, hoe hoër is die graad van geyktheid van die verhouding.

In sommige sintagmatiese leksikale betrekkinge is die verhouding baie geyk terwyl in ander dit nog nie so sterk gevestig is nie, maar daar is wel een of ander stereotiepe verhouding tussen die betrokke leksikale items. Gevalle soos blond $\times$ hare, roskam $\times$ perd, kous $\times$ voet, oase $\times$ woestyn, ens. vertoon 'n hoë graad van yking, terwyl in gevalle soos inlê $\times$ vrugte, inlê $\times$ vis en byl $\times$ kap, hamer $\times$ kap die graad van yking reeds laer is, soos weerspieël word in die variasie. In 'n geval soos speel $\times$ kinders is daar wel sprake van 'n stereotiepe verhouding, maar die geyktheid daarvan is nie besonder opvallend nie. Dit is daarom nie vreemd dat NW nie die betekenis van kind of kinders in die werkwoord speel se betekenis (in sy grondwaarde of eerste polisemiese waarde) geënkapsuleer sien nie:

(20)

speel: "jou vermaak (in lugtige beweging), aangenaam besig hou"

terwyl HAT wel erkenning verleen aan die stereotiepe verhouding wat die Afrikaanse moedertaalspreker sien tussen speel en kinders, sonder dat hy daarmee te kenne gee dat dit deel vorm van die betekenis van die werkwoord:

speel: "Jou vermaak; iets doen om jou aangenaam besig te hou veral gesê van kindèrs"

Hierdie metode van beskrywing (wat mens dikwels in Afrikaanse woordeboeke teëkom en wat in die verlede gekritiseer is) kan 'n meganisme word met die hulp waarvan rekenskap gegee kan word van die nondiskrete aard van woordbetekenis en die grys gebied tussen ensiklopediese en konvensionele betekenis. Wat interessant is, is dat albei woordeboeke erkenning verleen aan die stereotiepe sintagmatiese (leksikale) betrekking tussen speel en kind(ers) deur die aangawe van voorbeeldmateriaal. In albei gevalle verwys die eerste voorbeeldsin na kinders:
a. NW: Die kleintjies speel.
b. HAT: Die kinders speel. 


\section{Polisemie}

Een van die grondliggende aannames van die kognitiewe semantiek is dat leksikale items normaalweg polisemies is, d.w.s. daar is 'n beduidende aantal leksikale items wat elk meer as een verwante betekenisonderskeiding het. Tot nou toe is sintagmatiese leksikale betrekkinge beskryf as verhoudings tussen leksikale items, maar so 'n karakterisering is nie sonder meer aanvaarbaar nie. In De Stadler (1989: 78 e.v.) word aangetoon dat so 'n karakterisering ook nie kan geld van die paradigmatiese leksikale betrekkinge soos sinonimie en teenoorgesteldheid nie. Om maar een voorbeeld te noem: die sinonieme sterk en kragtig is sinoniem wat slegs sommige van hulle polisemiese waardes betref, maar ten opsigte van ander, soos die waarde "talryk, groot in getal" van sterk (Nasionale Woordeboek 1985: 492), is hulle nie sinoniem nie.

Wanneer ' $n$ leksikale item 'n sintagmatiese leksikale betrekking aangaan met ' $n$ ander, is dit insgelyks nie ten opsigte van al die polisemiese waardes van die betrokke item nie. Die werkwoord lees gaan 'n prototipiese sintagmatiese betrekking aan met die selfstandige naamwoord boek. Die werkwoord lees het egter verskillende polisemiese waardes, volgens die definisie van Nasionale Woordeboek (1985: 289):

(23) lees II (ge-) ww. 1. kennis neem van die inhoud van wat geskryf of gedruk is, 'n Boek -. Hy kan -, skryftekens ontsyfer, vertolk. Stil -, nie hardop nie. Tussen die reëls -, van wat gesê is, iets aflei wat nie uitdruklik vermeld is nie. 2. voorlees. Uit die Bybel - Iem. die les, leviete -, berispe, teregwys. 3. nasien, verbeter. Proewe -. 4. opmerk, te wete kom, gewaarword. Uit die natuur -. Iem. se gedagtes - . Op iem. se gesig iets - Afkorting l. 'leesbeurt, -saal, -toon, -trant (by 2).

Dit is slegs ten opsigte van waardes 1 en 2 wat lees 'n sintagmatiese leksikale betrekking met boek aangaan. Die ontwikkeling van afsonderlike polisemiese waardes volg dikwels uit die verbreking van 'n sintagmatiese verband, die spesialisering van 'n sintagmatiese verband, soos in waarde 3 in (23), of die metaforiese eksploitasie van 'n sintagmatiese verband, soos in waarde 4 in (23). Die term eksploitasie sinspeel hier op die feit dat die prototipiese sintagmatiese verband tussen lees en boek juis nie verlore gaan nie, maar gemetaforiseer word (vgl. verwante uitdrukkings soos Ek lees jou gedagtes, Iy is vir my ' $n$ oop boek, Ek lees jou soos ' $n$ oop boek, ens.).

Hierdie paar opmerkings wil slegs die aandag vestig op die feit dat sintagmatiese leksikale betrekkinge nie los gesien kan word van die polisemiese waardes van die leksikale items wat betrokke is nie. Die leksikale betrekkinge 

wat aangegaan word (ook paradigmatiese betrekkinge) is uiteindelik tussen
polisemiese waardes en nie tussen leksikale items nie.

\section{8. \\ Sintagmatiese leksikale betrekkinge in woordeboeke}

Die leksikograaf, soos sy taalkundige kollega, moet rekenskap gee van die leksikale betrekkinge wat verskillende leksikale items met mekaar aangaan, ook van die sintagmatiese leksikale betrekkinge. Laasgenoemde leksikale betrekking is juis belangrik omdat dit, anders as die paradigmatiese leksikale betrekkinge, 'n essensiële betekenisbetrekking is aangesien die betekenis van die een leksikale item in dié van die ander geënkapsuleer word. Hierdie essensiële betrekkinge behoort neerslag te vind in die leksikale definisies van 'n woordeboek. In hierdie paragraaf word, deur die vergelyking van enkele voorbeelde in twee bekende Afrikaanse verklarende woordeboeke (Nasionale Woordeboek en Verklarende Handwoordeboek van die Afrikaanse Taal), enkele leksikografiese meganismes aan die orde gestel waarmee hierdie essensiële betrekking beskryf kan word.6 Hierdie meganismes kan, as hulle dit nie reeds is nie, leksikografiese konvensies word met besondere taalteoretiese inhoud, soos aangetoon sal word.

In die eerste plek kan daar op die mees direkte wyse rekenskap gegee word van die sintagmatiese leksikale betrekking tussen twee leksikale items, $\mathrm{nl}$. in die formulering van die definisie self. Dit is die geval t.o.v. die leksikale betrekking tussen blokman en slaghuis in NW (NW = Nasionale Woordeboek, HAT = Verklarende Handwoordeboek van die Afrikaanse Taal; my kursivering in definisies - L.G. de S.):

blokman: "man wat 'n karkas in dele kap in 'n slaghuis."

HAT verantwoord die betrokke sintagmatiese leksikale betrekking slegs indirek, nl. deur gebruik te maak van 'n afgeleide vorm slagter (afgelei van die ww. slag wat weer as morfeem optree in die samestelling slaghuis):

\section{blokman: "Slagter wat vleis op 'n blok kap."}

Hoewel 'n minder direkte meganisme om die sintagmatiese leksikale verband mee te beskryf, aktiveer hierdie morfologiese verband wel die semantiese veld van slagwoorde (slag, slaghuis, slagding, slagtery, slagpale, ens.) wat die domein vorm waarbinne blokman betekenis kry.

Nie alleen word daar in NW van die leksikale betrekking tussen blokman en slaghuis rekenskap gegee nie, maar ook die unilateraliteit van die betrekking 
word op ' $n$ besondere wyse verantwoord: die geënkapsuleerde item vorm deel van die definiens, terwyl die item waarin eg. opgeneem is die definiendum (die lemma, soms ook trefwoord genoem) is. Wanneer die geënkapsuleerde item (slaghuis) se definisie egter geraadpleeg word, is daar, soos dit hoort, geen aanduiding van 'n sintagmatiese leksikale betrekking met blokman nie:

NW: "winkel waar vleis verkoop word; slagtery."

In die geval van 'n bilaterale leksikale betrekking sal albei items se definisies ' $n$ aanduiding moet gee van die bilateraliteit, soos in die geval van graaf $x$ spit in HAT:
a. graaf: "Werktuig bestaande uit 'n staalblad onder aan 'n steel, en gebruik om mee te spit, te delf of rond te verplaas ..." (eerste polisemiese waarde)
b. spit (ww.): "Die grond met 'n graaf of vurk omwerk; grawe: ..."

Die bilateraliteit van die betrokke leksikale betrekking spreek uit die teenwoordigheid van albei leksikale items in die woordeboekdefinisies, of as definiendum óf as definiens.

Soms word die sintagmatiese leksikale betrekking verreken in 'n samestelling, soos in die geval van non $\times$ klooster in NW:

$$
\text { non: "vrou wat die kloostergelofte afgelê het; kloostersuster." }
$$

Daar is verskeie voorbeelde waar een of albei die woordeboeke aanvoel dat daar een of ander stereotiepe/geykte verhouding bestaan tussen twee leksikale items, maar daar heers onsekerheid oor die graad van die geyktheid (of die betrekking het die leksikograaf ontgaan). In sulke gevalle word die betrekking verantwoord in die voorbeeld of voorbeelde wat by die definisie aangegee word. Die werkwoord speel roep byvoorbeeld die naamwoord kind op as die prototipiese doener van die betrokke handeling. Daar kan egter geoordeel word dat hierdie verhouding nog nie geyk genoeg is om as 'n (vaste) sintagmatiese leksikale betrekking erkenning te geniet nie. Albei woordeboeke gee egter erkenning aan die prototipe-verhouding tussen die twee leksikale items deur dit op te neem in die eerste voorbeeldsin van die grondwaarde van speel:

(29) NW: speel: "jou vermaak (in lugtige beweging), aangenaam besighou. Die kleintjies -."

HAT: speel: "Jou vermaak; iets doen om jou aangenaam besig te hou - veral gesê van kinders: Die kinders speel." 
Let ook daarop dat HAT die prototipiese waarde van speel, soos dit neerslag vind in die sintagmatiese betrekking met kind/kinders verantwoord met die formulering veral gesê van kinders. Die formule veral gesê van kan na my mening met vrug gebruik word om van die prototipiese aard van leksikale betekenis in woordeboeke rekenskap te gee.

Afgesien van die geyktheid van die sintagmatiese leksikale betrekking wat wisselende grade vertoon en daarom op verskillende maniere verantwoord kan word in die woordeboek, verraai 'n geykte sintagmatiese leksikale betrekking dikwels juis die prototipiese aard van 'n leksikale item se betekenis en moet dit in die woordeboek die nodige aandag kry. Woordeboeke bly dikwels in gebreke om presies dit te doen, soos blyk uit NW en HAT se hantering van galop. Hierdie leksikale item kan funksioneer as s.nw. en ww. en in albei gevalle gaan die betrokke leksikale item 'n geykte sintagmatiese leksikale betrekking aan met die s.nw. perd, ten spyte van die feit dat daar ook ander diere is wat hierdie handeling kan uitvoer. Met inagneming van die prototipiese siening van leksikale betekenis kan daar dus geargumenteer word dat die betekenis van galop die betekenis van perd geënkapsuleer het, of besig is om dit te doen. Teen hierdie agtergrond is die hantering van die item in die twee woordeboeke interessant:

NW: galop (s.nw.): "vinnige gang van 'n perd."

galop $(w w$.$) : "op 'n galop hardloop of ry." (eerste$ polisemiese waarde)

HAT: galop (s.nw.): "Ritmiese gang van 'n viervoetige dier, vinniger as 'n draf en bestaande uit 'n reeks kort spronge in elk waarvan die dier vir 'n oomblik met geen voet aan die grond raak nie: ...

galop (ww.): "Op 'n galop voortbeweeg ... 'n Perd galop vinniger as " $n$ bees."

In NW word daar op die mees direkte wyse rekenskap gegee van die prototipiese waarde van galop as s.nw. deur die opname van die s.nw. perd in die betrokke definiens. Die definisie van die $w w$. vereis van die woordeboekgebruiker 'n kruisverwysing na die s.nw.-definisie (deur die gebruik van die s.nw. galop in die definiens van die ww.-definisie), sodat die sintagmatiese verband, hoewel indirek, wel gelê word en daar steeds 'n erkenning is van die prototipiese waarde van galop. Daarteenoor verkjes HAT om nie die prototipiese waarde van galop te direk te verantwoord nie, soos blyk uit die gebruik van die superordinaat dier in die definiens van sy s.nw.-definisie. In die ww.definisie is daar ' $n$ vae suggestie van die prototipiese sintagmatiese verband met perd in die voorbeeldsin wat gebruik word.

Nog ' $n$ voorbeeld van die hantering van ' $n$ sintagmatiese leksikale betrekking wat ' $n$ prototipiese betekenis suggereer, kan teruggevind word in NW se definisie van harpoen, 'n selfstandige naamwoord wat as instrumentnaam- 
woord in 'n sintagmatiese leksikale betrekking tree met die pasiëntnaamwoord walvis:

$$
\begin{aligned}
& \text { harpoen: "werpspies met weerhake waarmee groot visse, veral } \\
& \text { walvisse, op see gedood word." }
\end{aligned}
$$

NW laat die klem val op die prototipiese verhouding tussen harpoen en walvis, terwyl HAT die enkapsulering van die betekenis van walvis in die betekenis van harpoen as afgehandel sien:

(32) harpoen: "Lang werpspies met weerhake aan die punt en 'n tou aan die agterent gebruik om walvisse mee te vang deur dit in die dier se lyf in te gooi of met kanon daarin te skiet."

Dat daar in 'n woordeboek rekenskap gegee moet word van die sintagmatiese leksikale betrekkinge wat leksikale items met mekaar aangaan, is seker. In hierdie paragrawe is daar gewys op enkele meganismes wat die leksikograaf kan aanwend. Uit 'n vergelyking van voorbeelde het dit egter ook duidelik geblyk dat daar verskillende veranderlikes is wat die leksikograaf in ag moet neem, soos die graad van geyktheid van die verhouding en die prototipiese betekenis wat deur sommige gevalle gesuggereer word.

\section{Perspektief}

Die bestaan van sintagmatiese leksikale betrekkinge tussen leksikale items word lank reeds erken, maar ek moet met Lipka (1990: 160) saamstem: "... on the whole, there is a long tradition of neglecting these (relationships) ...". In die Afrikaanse taalkundeliteratuur word daar haas geen aandag aan hierdie onderwerp gewy nie. 'n Ondersoek van die tersaaklike data verraai egter baie gou die belangrikheid van indringende navorsing op hierdie gebied. Sintagmatiese leksikale betrekkinge is essensiële betekenisbetrekkinge wat impliseer dat ' $n$ goeie begrip van die aard van hierdie tipe betrekking die taalkundige 'n tree of wat nader bring aan groter begrip van leksikale betekenis in die algemeen.

Die studie van sintagmatiese leksikale betrekkinge is, soos in paragraaf 8 geblyk het, ook van belang vir die leksikografie. Omdat leksikograwe (dikwels onbewustelik, vrees ek) in hulle beskrywing van die leksikon se struktuur en leksikale betekenis gebruik maak van hierdie betrekking, moet hulle vir hulself en hulle kliënte (die woordeboekgebruikers) kan rekenskap gee van die reikwydte en aard van hierdie verskynsel.

Binne die kognitiewe idioom is die studie van sintagmatiese leksikale betrekkinge egter ook van belang omdat dit op ' $n$ besondere wyse verraai hoe die 
mens sy kenniswêreld struktureer (vgl. byvoorbeeld die bespreking van die verskillende tipes in paragraaf 5 ).

In hierdie bydrae het maar slegs die punt van die ysberg sigbaar geword. Daar is talle vrae wat nog onbeantwoord bly, waaronder die volgende:

- Wat is die reikwydte van hierdie verskynsel?

- Op watter gronde, naas die (semantiese) rolgrammatikale oorwegings wat in paragraaf 5 gegeld het, kan daar tussen verskillende tipes sintagmatiese leksikale betrekkinge onderskei word?

Wat is die implikasies van die feit dat sommige van die betrekkinge unilateraal is, terwyl ander bilateraal is?

In watter rigting vind enkapsulering plaas? Waarom juis in dié besondere rigting? Word die betekenis van die meer algemene term byvoorbeeld in dié van die meer spesifieke term geënkapsuleer, of is daar ander oorwegings wat geld, soos byvoorbeeld dat werkwoorde makliker die betekenisse van die naamwoorde wat na hulle argumente verwys, enkapsuleer?

Hierdie en talle ander vrae eis verdere navorsing oor hierdie onderwerp, en daarom het dit miskien in dié geval, na die werk van Porzig in 1934, nodig geword om die wiel te herontdek, maar ook om die ontwerp van die wiel te verbeter.

\section{Bibliografie}

Aitchison, J. 1987. Words in the Mind. Oxford: Basil Blackwell.

Cruse, D.A. 1986. Lexical Semantics: Cambridge, Londen, New York: Cambridge University Press. De Stadler, L.G. 1989. Afrikanse semantiek. Johannesburg. Southern.

Fauconnier, G. 1984. Mental Spaces. Cambridge, Massachusetts: MTT Press.

Geeraerts, D. 1986. Woordbetekenis: Een oberzicht oan de lexicale semantiek. Leuven en Amersfoort: Acco.

Gouws, R.H. 1989 Leksikografie. Pretoria, Kaapstad: Academica.

Lakoff, G. 1987. Women, Fire and Dangerous Things: What Categories Reveal about the Mind. Chicago: Chicago University Press.

Lakoff, G. en M. Johnson. 1980. Metaphors we Live by. Chicago: Chicago University Press.

Langacker, R.W. 1987. Foundations of Cognitioe Grammar, Vol. I: Theoretical Prerequisites. Stanford: Stanford University Press.

Langacker, R.W. 1991 (te verskyn). Foundations of Cognitioe Grammar, Vol. II: Descriptioe Application. Stanford: Stänford University Press.

Lipka, L. 1990. An Outline of English Lexicology. Tübingen: Max Niemeyer Verlag.

Lyons, J. 1977. Semantics. Cambridge: Cambridge University Press. 
Porzig, W. 1934. Wesenhafte Bedeutungsbeziehungen. Beiträge zur deutschen Sprache und Literatur 58: 70-97.

Porzig, W. 1950. Das Wunder der Sprache. Bern: Francke.

Rudzka-Ostyn, B. (Red.). 1985. Topics in Cognitioe Linguistics. Amsterdam: John Benjamin.

Taylor, J.R. 1989. Linguistic Categorization: Prototypes in Linguistic Theory. Oxford: Clarendon Press. 